\title{
Catalytic Converters for Vehicle Exhaust: Fundamental Aspects and Technology Overview for Newcomers to the Field
}

\author{
Emmy Kritsanaviparkporn ${ }^{1}$, Francisco M. Baena-Moreno ${ }^{1,2, * \mathbb{D}}$ and T. R. Reina ${ }^{1, *(\mathbb{D})}$ \\ 1 Department of Chemical and Process Engineering, University of Surrey, Guildford GU2 7XH, UK; \\ pk00425@surrey.ac.uk \\ 2 Chemical and Environmental Engineering Department, Technical School of Engineering, University of Seville, \\ C/Camino de los Descubrimientos s/n, 41092 Sevilla, Spain \\ * Correspondence: fbaena2@us.es (F.M.B.-M.); t.ramirezreina@surrey.ac.uk (T.R.R.)
}

Citation: Kritsanaviparkporn, E. Baena-Moreno, F.M.; Reina, T.R. Catalytic Converters for Vehicle Exhaust: Fundamental Aspects and Technology Overview for Newcomers to the Field. Chemistry 2021, 3, 630-646. https://doi.org/10.3390/ chemistry3020044

Academic Editor: Gianguido Ramis

Received: 5 April 2021

Accepted: 12 May 2021

Published: 20 May 2021

Publisher's Note: MDPI stays neutral with regard to jurisdictional claims in published maps and institutional affiliations.

Copyright: (c) 2021 by the authors. Licensee MDPI, Basel, Switzerland. This article is an open access article distributed under the terms and conditions of the Creative Commons Attribution (CC BY) license (https:// creativecommons.org/licenses/by/ $4.0 /)$.

\begin{abstract}
This works aims to provide an understanding on basic chemical kinetics pertaining to three-way catalytic (TWC) converters from an educational perspective, aimed at those novel readers in this field. Rate of reactions and its factors are explained, showcasing that the chosen catalyst is the main factor affecting the overall rate of reaction. Furthermore, this overview revisit insights of the catalytic converter structure and the environmental issues that come along with it. Lastly, the chemical and physical properties of the reactants and products-pollutant and less-toxic gases-are discussed, in order to gather a better understanding of the reactants and products that enters a catalytic converter.
\end{abstract}

Keywords: catalytic convertes; emissions; overview; catalysis

\section{Introduction}

The use of fossil fuels in the transport sector has increased the greenhouse gas (GHG) emissions during the last decades [1,2]. Fossil transport fuels such as gasoline or diesel release exhaust gases composed by carbon dioxide $\left(\mathrm{CO}_{2}\right)$, methane $\left(\mathrm{CH}_{4}\right)$, nitrous oxide $\left(\mathrm{N}_{2} \mathrm{O}\right)$, carbon monoxide (CO) and hydrofluorocarbons (HFCs) [3]. Indeed, the GHG from the transport sector amounts $28 \%$ of the total US emissions [1]. This percentage is lower (19.4\%) for European Union, but still important [4]. The reduction of these emissions are a big challenge for breaking the so called climate change cycle [5]. Some strategies have been proposed to solve the problem of emissions in the transport sector. Increasing the share of renewable energy and moving towards hydrogen as an energy vector are the preferred actions [6]. In fact, powering our vehicles through fuel cells or hydrogen internal combustion engines is already technically feasible [7], but overcoming the overall cost attached to these two technologies is still a challenge in the path towards a low-carbon transport sector [7]. In this line, other options must be explored. As presented in a recent review [8], advances in engine technologies are placing additional demands on emission control catalysts. In this sense, the use of catalytic converters to reduce exhaust gases from vehicles and converting them into unharmful compounds is widely extended [9]. Among catalytic converters, three-way catalytic (TWC) converters have been the state of the art technology since 1970 [10].

TWC converters are a tool used for reducing the emission of pollutant gases that are present in the exhaust gas released from an internal combustion engine of an automobile [11]. TWC is chosen over a two-way catalytic converter in automobiles because it can reduce the emissions of the $\mathrm{N}_{2} \mathrm{O}$ gases, as well as the emission of $\mathrm{CO}$ gas and unburned hydrocarbons. Two-way catalytic converters will only be able to reduce the emissions of $\mathrm{CO}$ gas and unburned hydrocarbons, due to the catalysts used and the reactions that occur [11]. By using the concept of heterogeneous catalysis and rate of reaction, a honeycomb ceramic structure (usually coated with $\mathrm{Al}_{2} \mathrm{O}_{3}$ ), which acts as catalyst support, 
is used. The main reason is that it allows the best possible contact between the flowing exhaust gas and the catalyst surface [12]. The honeycomb ceramic structure is a catalyst support that provides a large surface area, in order for redox reactions to take place at a higher rate and efficiency. A large surface area, along as temperature and pressure, is one of the main factors that provides a higher rate of reaction [13]. The structure is then coated with a solution containing different noble metal nitrates such as palladium nitrate, rhodium nitrate and platinum nitrate [14]. The honeycomb structure facilitates the flow of gas through the converter and controls any pressure drops.

Even though TWC converters are widely used commercially, and fundamental aspects and technology have been described [15-20], a review from an educational perspective is still missing. Hence this work is a useful initial resource for newcomers to the field to familiarize them in a direct and clear manner with the main concepts and characteristics of TWC technology. Therefore, the goal of this paper is to offer an overview of the main fundamental working principles of TWC from an educational perspective. To this end, this work is organised as follows. First, the working principles of TWC converters are explained. Afterwards, the most common structures used for the devices are reviewed, along with the typical working conditions for a TWC. The rates of reaction are subsequently provided, focusing finally on pollutant gases reduction.

\section{Working Principles of Three-Way Catalytic Converters}

Internal combustion engines use the exhaust stroke to expel the spent gases, via the exhaust system, where the harmful emissions are then passed through a muffler-type looking device which is the catalytic converter [12,21]. Components of the spent gases consist of unburned hydrocarbons, NO, and CO [21]. As mentioned above, the main purpose of the catalytic converter is to reduce the original harmful emissions to the most acceptable levels, by the means of catalyst controlled chemical reactions. Therefore, there are needs to be the most careful attention to the engine design, before venting out the gas into the air [12].

The majority of automobile catalytic converters have a design of a monolithic structure, which is coated with an alumina washcoat. The monolithic structure is referred to as the core of the catalytic converter, where the core is typically a ceramic monolith with a honeycomb configuration. The purpose of the honeycomb structure is to allow for the heterogeneous catalysis to occur on the surface of the honeycomb structure. Metallic monolith is made out of FeCrAl where it has high heat resistance. The washcoat can also consist of aluminum oxide, silicon dioxide, titanium dioxide or a mixture of silica and alumina [22].

Catalytic converters use metallic catalysts to promote the desired reactions at lower temperatures [14]. Common metal catalysts used could be a base metal (such as chromium) and noble metals, such as platinum, palladium, and rhodium [14]. These catalysts can be used for redox reactions; the reduction of $\mathrm{N}_{2} \mathrm{O}$ and the oxidation of unburned hydrocarbons and CO. If platinum, palladium, and rhodium metals are used, these can be a part of the Platinum Group of Metals Solution (PGM Solution), which is also used to coat the honeycomb structure. This would allow for heterogeneous catalysis to take place on the surface of the core, allowing for the production of less toxic gases $\left(\mathrm{CO}_{2}\right.$, nitrogen and water vapour) to be produced [23].

Another component of the catalytic converter is its metal casing that surrounds the core of the catalytic converter. This metal casing directs the exhaust gas flow through the catalyst bed. The metal casing is usually made out of stainless steel, but since lowtemperature catalysts are used, stainless steel may not be necessary for the construction of the catalytic converter [24]. A diagram of a TWC converter is shown in Figure 1. 


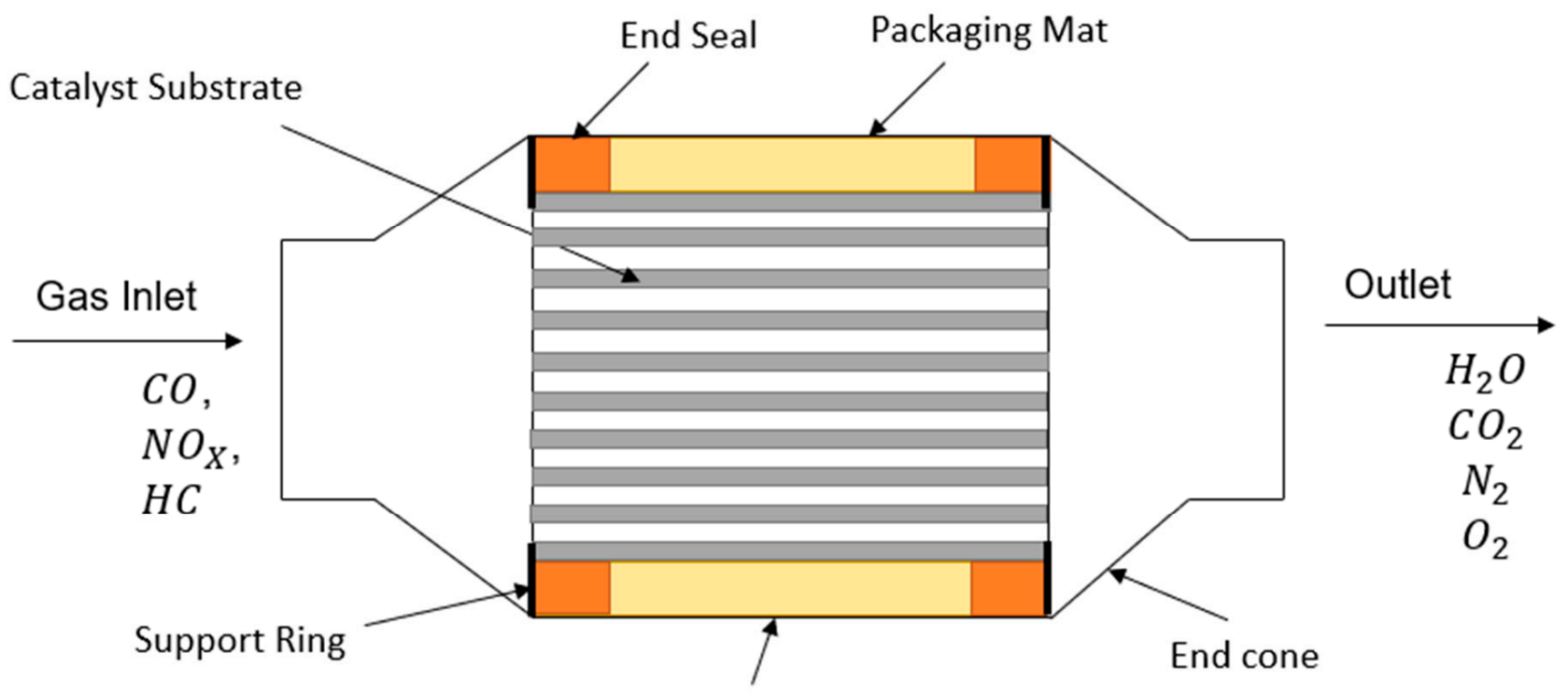

Steel Shell

Figure 1. Automobile catalytic converter. Adapted from $[25,26]$.

The initial step in heterogeneous catalysis is the adsorption of the reactants, where adsorption refers to the binding of molecules to a surface [12]. Adsorption would occur because of the high reactivity of the atoms/ions on the surface of the solid, facilitating the honeycomb the flow of gas through the converter and controls pressure drop. Since the composition of the exhaust gas also contains oxygen gas and the pollutant gases $\left(\mathrm{CO}, \mathrm{N}_{2} \mathrm{O}\right.$ and unburned hydrocarbons), oxygen atoms are made available to react with the other adsorbed pollutant gases. In the case of $\mathrm{CO}$, the oxygen atom reacts with $\mathrm{CO}$ yielding $\mathrm{CO}_{2}$, and so, as the final step in heterogeneous catalysis, $\mathrm{CO}_{2}$ desorbs from the metal surface and is released as a product out of the catalytic converter. This concept is identical for both the $\mathrm{N}_{2} \mathrm{O}$ and the unburned hydrocarbons.

Briefly, in a TWC converter, the simultaneous redox reactions consist of a three-way system which controls emissions by oxidation of the unburned hydrocarbons and $\mathrm{CO}$ and by the reduction of the $\mathrm{NO}_{X}$ [27], (unlike two-way catalytic converters, where only 2 oxidation reactions occurs, so the $\mathrm{N}_{2} \mathrm{O}$ are not reduced), so the three-way catalytic converter would have the following functions:

(1) Oxidation of unburned hydrocarbons, where oxygen gas is present in the exhaust gas, has its bonds broken and the oxygen atom reacts with the unburned hydrocarbons to produce $\mathrm{CO}_{2}$ and water vapour as the final products. An example would be the oxidation of benzene (Equation (1)):

$$
2 \mathrm{C}_{6} \mathrm{H}_{6(g)}+15 \mathrm{O}_{2(g)} \rightarrow 12 \mathrm{CO}_{2(g)}+2 \mathrm{H}_{2} \mathrm{O}_{(l)}
$$

In this particular reaction, palladium or platinum would be used. Even though palladium and platinum both have similar chemical properties [28], palladium would be preferred over platinum because of the decline in effectiveness of the converter, which means that platinum deactivates faster than palladium, therefore the converter efficiency would decrease very fast [29].

(2) Oxidation of $\mathrm{CO}$ to form $\mathrm{CO}_{2}$ by using either catalysts platinum or palladium nitrate. Oxygen gas that is present in exhaust gases is adsorbed to the surface of the honeycomb ceramic, and so the oxygen bond is weakened and so the oxygen atom reacts with $\mathrm{CO}$ to give $\mathrm{CO}_{2}$ (Equation (2)):

$$
\mathrm{CO}_{(g)}+\mathrm{O}_{2(g)} \rightarrow \mathrm{CO}_{2(g)}
$$


Either platinum of palladium can be used as a catalyst for this reaction, as they both have very similar physical and chemical properties.

(3) Reduction of $\mathrm{N}_{2} \mathrm{O}$ to give stable nitrogen and oxygen gas (Equation (3)). Since this is a reduction reaction, rhodium is used instead. Since it is a rare type of noble metal, rhodium is usually alloyed with platinum or palladium.

$$
2 \mathrm{NO}_{\mathrm{X}(\mathrm{g})} \rightarrow \mathrm{XO}_{2(\mathrm{~g})}+\mathrm{N}_{2(g)}
$$

Rhodium metal is used for this reduction reaction because it is an oxidising agent (a substance that loses electrons), compared to the other reducing agents, palladium and platinum. For these redox reactions the amount of oxygen gas present in the exhaust gas is a critical parameter. If there was a higher concentration of oxygen gas present in the exhaust gas than required, the system is defined as lean, so oxidation of unburned hydrocarbons and $\mathrm{CO}$ would more likely occur, as there is less fuel in the automobile. However, if there is a lower concentration of oxygen gas present in the exhaust gas, the system is defined as rich, so reduction of $\mathrm{N}_{2} \mathrm{O}$ are more likely to occur as there is a higher concentration of fuel than needed. Therefore, the efficiency of catalytic converters are not always $100 \%$ efficient [11].

In order to achieve the best efficiency of a catalytic converter, the fuel/air ratio, which defines how much fuel or excess air is inside the catalytic converter, can be measured using a feedback control loop system, where the metering of the fuel needs to be precisely measured, and the concentration of the oxygen leaving the catalytic converter is measured using a specific sensor [27].

\section{Structure of Three-Way Catalytic Converters}

To construct a catalytic converter, the following components must be considered:

(1) Catalyst Core (substrate).

Typically, for a catalytic converter, the core is an open-channel ceramic monolith or either a metallic honeycomb substrate that provides an area for the catalyst [30]. The most commonly used structure, the honeycomb ceramic, is designed to maximize the surface area (Figure 2) [31]. A larger surface area would result in a higher reaction rate [32]. Cordierite $\left(2 \mathrm{MgO}-2 \mathrm{Al}_{2} \mathrm{O}_{3}-5 \mathrm{SiO}_{2}\right)$ is the most commonly used type of monolith because it has a high surface area, large open frontal area, low heat capacity, and good mechanical strength [30,33]. Figure 2 displays how the catalyst is placed on the monolith channel.

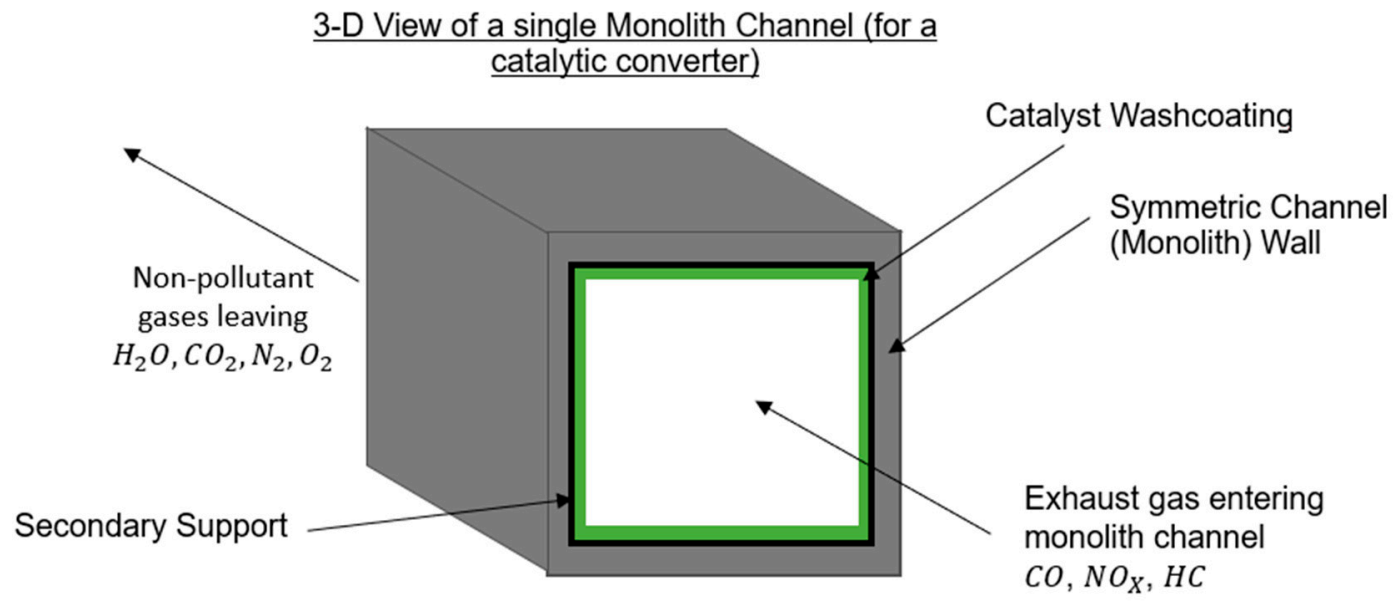

Figure 2. Reactants passing through a single monolith channel and exiting as products. Monolith wall = solid grey colour, secondary support $=$ black and catalyst layer $=$ green. Adapted from $[34,35]$. 


\section{(2) Washcoat}

A coat of supported catalysts is applied to the surface of the honeycomb ceramic structure. A thin coating of a wet-based slurry is directly applied on the highly porous material, which contains alumina as well as different metal oxides or zeolites [36]. The honeycomb ceramic structure is usually coated with $\gamma-\mathrm{Al}_{2} \mathrm{O}_{3}$, due to its high resistance towards higher temperatures [14], which contains the catalyst materials of about $0.1-0.15 \%$, $20 \%$ cerium oxide, and stabilisers such as barium oxide. Rare earth and alkaline ions can improve stabilisation [14]. Cerium oxide is mixed with the catalyst materials as it is used to improve the thermal stability of alumina, and can store and release $\mathrm{O}_{2}$ in, respectively, lean and rich conditions [37]. This thin coating of the wet based slurry is then dried up and calcined, which is the heating of solids to a high temperature to remove volatile substances.

There has been research done to directly apply the metal catalysts onto the surface of the honeycomb ceramic without the involvement of drying and calcination. According to [38], this method involves the use of electrolysis (the electroplating technique), where a washcoat of $\gamma-\mathrm{Al}_{2} \mathrm{O}_{3}$ on nickel oxide (NiO) catalyst is electroplated onto the $\mathrm{FeCrAl}$ substrate; the honeycomb ceramic is submerged into a solution and alumina ions are directly transferred to the honeycomb surface. A schematic diagram showing the set-up of the experiment is shown in Figure 3. As a result, [38] concluded that the CO emissions were below $7 \mathrm{ppm}$ when a catalytic converter of this experiment was used.

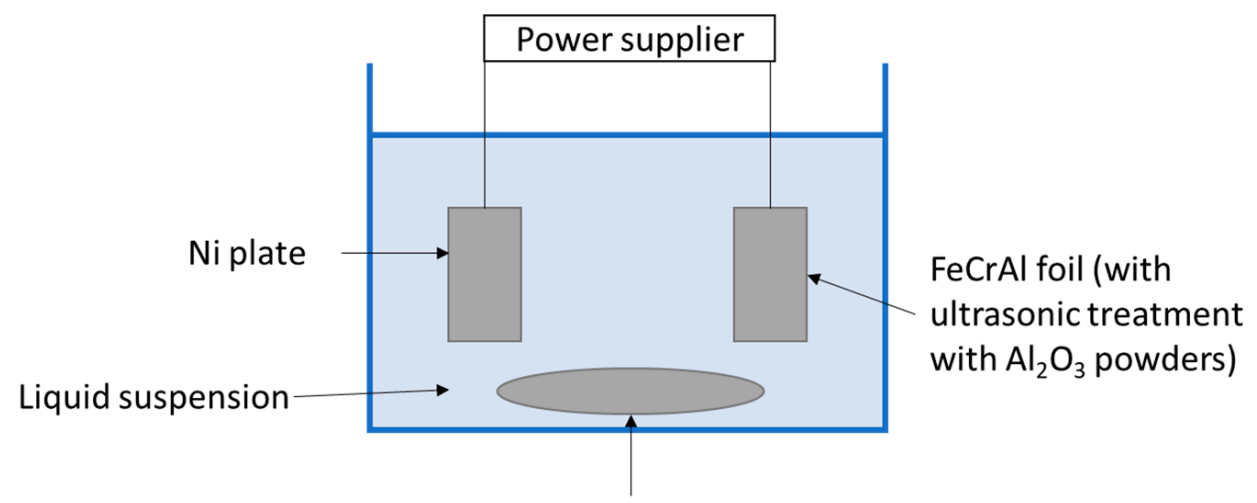

\section{Electromagnetic stirrer}

Figure 3. Schematic diagram of the electroplating process. Adapted from [38].

Washcoat materials are selected in order to form a rough, irregular surface, which will increase the surface area compared to the smooth surface of the substrate. This coat will protect the sintering of catalytic metal particles even at high temperatures that can go up to 1000 Degrees Celsius [39].

\section{(3) Catalyst Solution}

Noble metals are the most commonly used heterogeneous catalysts, as they can be made more thermally resistant to reduced low-temperature activity. Another excellent characteristic is that they provide equivalent catalytic activation with smaller volumes than do base metals. Therefore, a small number of noble metals in the form of a solution, such as palladium, platinum and rhodium nitrates, is used to coat on the surface of a honeycomb ceramic [14]. This type of heterogeneous catalyst solution, called a PGM Solution, is a solution of platinum group metals that are highly resistant to chemical attacks and have very high-temperature resistance and corrosion resistance [40], therefore deemed to be the most appropriate catalyst solution in a catalytic converter [41]. The PGM Solution contains platinum, palladium and rhodium, where its chemical and physical properties are shown in Table 1, and is coated onto the honeycomb ceramic structure, supported by a coat of supported catalysts of thermal resistant metals [41]. 
Table 1. Chemical and physical properties of PGM metals. Adapted from [42].

\begin{tabular}{cccc}
\hline Chemical Name (Symbol) & Platinum $(\mathbf{P t})$ & Palladium $\mathbf{( P d )}$ & Rhodium $(\mathbf{R h})$ \\
\hline Density $\left(\mathrm{g} / \mathrm{cm}^{3}\right)$ & 21.45 & 12.02 & 12.41 \\
Melting Point $\left({ }^{\circ} \mathrm{C}\right)$ & 1769 & 1554 & 1960 \\
Vickers Hardness No. & 40 & 70 & 101 \\
Thermal Conductivity $\left(\mathrm{W} / \mathrm{M} /{ }^{\circ} \mathrm{C}\right)$ & 73 & 17 & 150 \\
Tensile Strength $\left(\mathrm{kg} / \mathrm{mm}^{2}\right)$ & 14 & 71 \\
Physical Properties & Soft, ductile and resistant to oxidation and high & Excellent performance \\
\hline
\end{tabular}

The quantity of platinum, palladium and rhodium used in auto catalysts depends on the vehicle type, manufacturer, country, year and additional factors [40]. In TWC Converters, the ratio of $\mathrm{Pt} / \mathrm{Rh}$ is 5 to 1 , and the ratio of $\mathrm{Pd} / \mathrm{Rh}$ is 7 to 1 [40].

As demand for TWC converters are increasing, the demand for PGM is also increasing [40]. About $15-20 \%$ of the world demand for platinum comes with recycling from used catalytic converters, however, the amount of platinum required is not enough to meet the growing world demand, hence the shrinking in platinum reserves and the increase in platinum price. Therefore, the high value of PGM has stimulated the recovery of PGM from used catalytic converters [40], and it is widely practiced. One of the common methods of PGM recovery is shown in Figure 4. Recovering PGM is very important as it provides supplementary source to the mining of these metals, therefore protecting the environment by limiting the number of waste disposal, saving natural resources exploitation, limiting electricity consumption and diminishing pollutant emission [40].

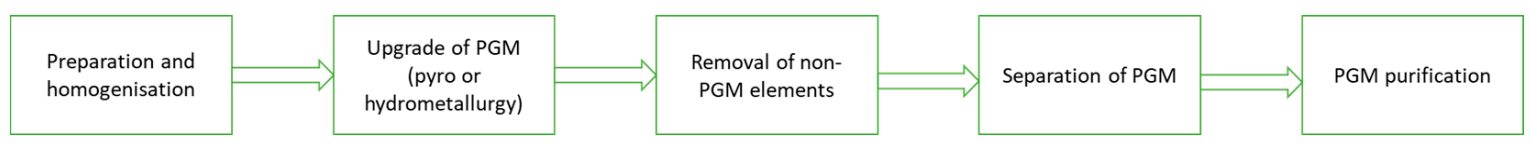

Figure 4. Main steps to recover PGM from used catalytic converters. Adapted from [40].

\section{(4) Metal Casing}

Due to mechanical vibrations inside the car and thermal stresses, the metal casing is essential [43]. Furthermore, a metal casing is used to direct the exhaust gas flow, since gas flow is a scalar quantity (only has a magnitude but no direction). High thermal stress can alter the shape of the substrate easily, so a metal casing is required to hold the ceramic together. At high thermal stress, this can result in permanent plastic deformations [43]. The metal casing can be produced through the canning process. A thinned wall metal casing is desired [44], as this can allow better heat transfer to the surroundings, to prevent the catalytic converter from reaching temperatures of up to $1000^{\circ} \mathrm{C}$. However, the question of durability and efficiency is considered, as high temperatures can result in deformation of the catalytic converter $[45,46]$.

In another design, the option of using a support mat is considered, where it is placed in between the honeycomb ceramic and the steel casing acting as thermal insulation. A schematic diagram is shown in Figure 5. A support mat purpose is to act as a mechanical support of the monolith, provide thermal insulation and minimize the potential for shell deformation [45]. Shells may be a variety of grades of stainless steel and are an integral part of the exhaust system. Therefore, the designer should take the thermal expansion differences and yield strengths of various materials into consideration [45]. Substrate and the steel shell of the catalytic converter have different thermal coefficients of thermal expansion, so there is a gap present between both sections. The gap expands and contracts as the converter cycles in temperature during its use [45]. Gap expansion can be minimized by adjusting the material of the stainless-steel shell, where it is suggested to use ferritic steel shells (SS409), where is has about 50\% lower thermal expansion compared to austenitic (SS310) [45,47]. 


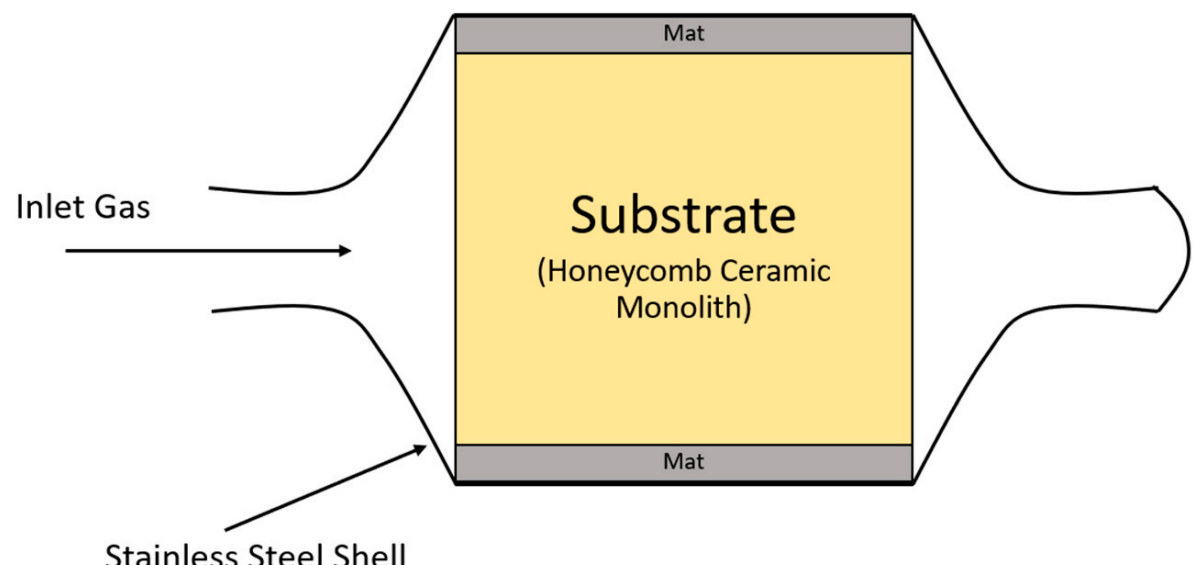

Figure 5. Diagram of converter with the mat. Adapted from [45].

\section{Conditions in Catalytic Converters}

\subsection{Temperature}

The temperature conditions inside the catalytic converter must be able to minimize the cold-start emissions, as well as maintain a high conversion efficiency of pollutant gases to non-pollutant gases. A summary of the catalyst light-off temperature and operating temperature can be shown in Table 2 below.

Table 2. Summary of temperature ranges for a specific condition in a catalytic converter. Adapted from $[37,48-50]$.

\begin{tabular}{cc}
\hline Conditions & Temperature $\left({ }^{\circ} \mathbf{C}\right)$ \\
\hline Catalyst Light-Off Temperature & $250-300$ \\
Operating Temperature & $450-500$ \\
Pt sinters & 700 \\
Pt-Rd and Pt-Rh Alloy forms & $700-800$ \\
Alumina Sinters & $800-900$ \\
Ceramic monolith softens & $1300-1400$ \\
Metal Monolith melts & $1500-1600$ \\
Pellet Melting & $>1900$ \\
\hline
\end{tabular}

\subsection{Cold Start Emissions}

An automobile engine usually begins from a cold start; therefore, the catalytic converter is starting up from a cold start, i.e., the catalytic converter is at the same temperature as its surroundings and the catalyst conversion efficiency is effectively zero at this point. The catalytic converter is not working to the specified operating temperature (optimum temperature) [24], where the operating temperature is suggested to be around $400-800{ }^{\circ} \mathrm{C}[37,51]$. Above this range the thermal aging process begins to accelerate and the noble metals and the carrier begins to sinter, thus shrinking down the active surface area [51]. Therefore, there is a certain time interval that is required for the temperature of the catalytic converter to increase from the ambient temperature $\left(15-25^{\circ} \mathrm{C}\right)$, to its optimum temperature. During this period, cold-start emissions are present. Cold-start emissions are defined as the emissions produced by an engine during the initial warm-up period, after a sufficiently long period of non-use, and before the engine, catalytic converter, or any other emission reduction systems would reach their optimum operating condition [52]. According to [48] and [50], the so-called light-off temperature, which is the certain threshold temperature for the catalyst to convert harmful emissions, normally exists at around 250-300 ${ }^{\circ} \mathrm{C}$. The term 'light-off temperature' is also used to describe the temperature at which the catalyst becomes more than $50 \%$ effective [50]. Therefore, high levels of exhaust emission are transferred into the atmosphere when the exhaust temperature is low [48]. 
Cold start emissions are considered a problem in the automobile industry because pollutant gases are emitted to the surroundings when the catalytic converter is starting up $[48,49,53]$. In a study recently conducted [48], it was found that the maximum concentrations of $\mathrm{CO}$ and unburned hydrocarbons that we emitted out of the exhaust engine ranged from $950 \mathrm{ppm}$ to $8400 \mathrm{ppm}$ and from $220 \mathrm{ppm}$ to $28,000 \mathrm{ppm}$, respectively. High emissions of these pollutant gas were caused by poor cylinder combustion and catalyst efficiency. These two aspects were improved in [48]. Various techniques such as using the retard ignition timing method, adjusting the air/fuel ratio inside the catalytic converter and the use of thermal insultation materials were used, as one of the few key thermal management techniques to control the emission of exhaust gases. Table 3 summarises just a few key thermal management methods to minimize the light-off period and the cumulative emission of exhaust gases.

Table 3. Overview of catalyst light-off time reductions and the cumulative emission reductions with different thermal management methods. Adapted from [48].

\begin{tabular}{|c|c|c|}
\hline Thermal Management Methods & Light-off Time Reduction & Cumulative Emission Reduction \\
\hline Start of combustion delay & $80 \%$ & n.a. \\
\hline Higher idle speed & $90 \%$ & n.a. \\
\hline Variable Valve Timing & n.a. & $30 \%$ \\
\hline Air/fuel ratio adjustment & n.a. & n.a. \\
\hline After-treatment layout & $26 \%$ & n.a. \\
\hline Burner & $40 \%$ & n.a. \\
\hline Reformer & $50 \%$ & n.a. \\
\hline Thermal energy storage device & $70 \%$ & n.a. \\
\hline EHC & $50 \%$ & n.a. \\
\hline Coolant and Lubricating Oil Heating & n.a. & $20 \%$ \\
\hline
\end{tabular}

The main methods to shorten the warm-up period would be heating with electrical power, heating with an external combustion chamber, and installing an auxiliary smallcapacity catalytic converter [54]. However, they all employ active means which would require an external energy source along with a control unit.

\subsection{Catalyst Conversion Efficiency}

As the temperature of the catalyst increases, the catalyst conversion efficiency would increase for $\mathrm{CO}$ and unburned hydrocarbons [50]. To obtain the catalyst conversion efficiency mathematically, which is the ratio of the rate of mass removal in the catalyst of a particular constituent of interest to the mass flow rate of that constituent into the catalyst, Equation (4) for unburned is used [50]. There is a positive correlation between the catalyst conversion efficiency and the temperature (Figure 6).

$$
\eta_{\text {cat }}=\frac{\dot{m}_{H C, \text { in }}-\dot{m}_{H C, o u t}}{\dot{m}_{H C, \text { in }}}
$$

Figure 6 shows a positive trend as the temperature increases, the catalyst conversion efficiency increases. At high enough temperatures of around 350 to $450{ }^{\circ} \mathrm{C}$ as shown on the graph, the steady-state conversion efficiencies of $\mathrm{CO}$ and $\mathrm{HC}$ are typically $98-99$ percent and 95 percent or above, respectively [50].

High temperatures were once the limiting factor for converter designs, as higher temperatures can lead to sintering, resulting in a decrease in fraction of metal available for catalytic reactions to occur as well as increased aging of coating when the gas inlet temperatures into the converter is above $850^{\circ} \mathrm{C}$ [49]. As a result, new washcoat formulations were developed, where gas inlet temperatures of $1050^{\circ} \mathrm{C}$ can be attained without the impairment of the coating; high temperature coating of $1050^{\circ} \mathrm{C}$ for $24 \mathrm{~h}$ can still maintain a very high conversion efficiency for hydrocarbons at $98 \%$ [49]. 


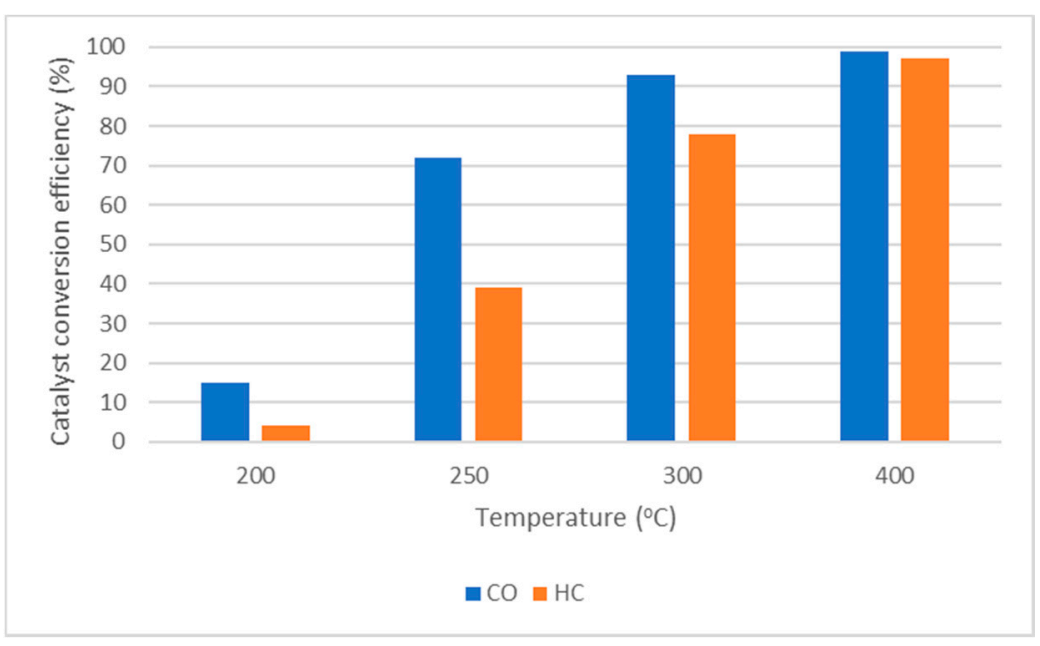

Figure 6. Conversion efficiency for $\mathrm{CO}$ and $\mathrm{HC}$ as a function of temperature for a typical oxidizing catalytic converter. Adapted from [50].

Furthermore, from [48], in order to maintain the temperature of the catalyst to work at its optimum, suggestions of improving the insulating material was discussed. A study from this paper showed that the effect of partially ceramic coated pistons on the cold-start emissions of engine would increase the temperature by around $100^{\circ} \mathrm{C}$, as well as reduce the peak values of Hydrocarbon emission by up to $15 \%$. Furthermore, the efficiency of a precious metal-containing catalyst declines very steeply for a temperature below $350{ }^{\circ} \mathrm{C}$, and cites the importance of using phase-change-material, so some of the thermal energy of exhaust gases are stored within the phase-changing material where the catalyst would be embedded [54].

In summary, if the catalysts is at its optimum at a lower operating temperature of around $300{ }^{\circ} \mathrm{C}$, then a washcoat applied must be improved to withstand higher temperatures during the cold start period i.e., the wash coat needs to be able to withstand temperatures of around 950 to $1050{ }^{\circ} \mathrm{C}$ [24]. Furthermore, since it is expected that catalysts work at a lower temperature, expensive stainless steel is not required during the construction of the catalytic converter [24].

\subsection{Pressure}

The pressure drop is considered an important design parameter as it represents energy loss [38], and an increase in pressure drop can be an indication that catalyst plugging may occur [31]. When designing the monolithic substrates, there must be a trade-off between the pressure drop and the total geometric surface. This is because due to increasing pressure drop is a major issue as there is significant engine loss in terms of power and fuel economy [55]. According to [55], an engine will lose about 300W of power per $1000 \mathrm{~Pa}$ of pressure loss. However, increasing the total geometric surface area i.e., the higher the cpsi, the higher the conversion is [31]. Studies and experiments have been conducted to minimize the pressure drop, usually to adjust the substrate geometry and the flow distribution.

Experiments to adjust the geometry of the honeycomb ceramic were done to optimize the flow distribution inside the catalytic converter so the pressure drop remains low. Before catalytic converter technologies were improved, substrate geometry inside the catalytic converter used to be in a pellet form using spherical particular of aluminum oxide, before being replaced with a honeycomb monolith structure, as having a honeycomb monolith structure would ensure a lower pressure drop of over $70 \%$ by having a high open frontal area (where it is defined as a function of wall thickness, cell spacing and cell density), which results in little resistance to flow [56].

The geometry structure of the monolith would affect the pressure drop, where their hypothesis states that the channel geometry would affect the pressure drop from the monolith honeycomb [57]. An experiment was conducted and assumed that the flow of gas 
would follow the Poiseuille flow and constant apparent permeability. Data of the channel velocity and the pressure drop was plotted for different void fractions of $0.60,0.66,0.73$, 0.84 . The channel velocity of the gas was in $\mathrm{m} / \mathrm{s}$ and was increased from $1 \mathrm{~m} / \mathrm{s}$ to $6 \mathrm{~m} / \mathrm{s}$. For all void fractions, as the channel velocity increases, the pressure drop entering and leaving the monolith increases.

As stated in the opening paragraph of the section, another factor that can be directly adjusted would be the flow distribution. The flow distribution would have a significant effect on the pressure drop of the catalytic converter [58]. Adjusting the flow distribution would improve power consumption and can also provide higher conversion efficiency. Adjusting the geometry of the honeycomb ceramic by using square and hexagonal cells was carried out in [55]. The authors pursued improving the pressure drop and therefore the conversion efficiency. Dimensions of 600 cells per square inch (cpsi) and a thickness of $0.114 \mathrm{~mm}$ and $400 \mathrm{cpsi}$ and a thickness of $0.089 \mathrm{~mm}$ for square and hexagonal shaped cells were compared, respectively. Air at uniform velocities of 5, 10, 15, 20 and $25 \mathrm{~m} / \mathrm{s}$ were used, with an air inlet temperature of $293 \mathrm{~K}$ and an outlet pressure at atmospheric pressure. Assuming a constant hydraulic diameter was present, it was found that the hexagonal cell geometry would reduce the pressure drop more than the square cell geometry. It is suggested in [55] that the hexagonal-shaped cell gives better mechanical performance (lower pressure drop), which proves that it would be better for flow distribution, so less energy consumption is needed for the catalytic converter. Experimental and Simulation pressure drops were recorded, and the root-square (RS) and root mean square (RMS) was calculated for each inlet air velocity. Tables $4-6$ show that for both a square and hexagonal shaped cell, with increasing air velocity, there is an increasing pressure drop. From Table 4, a hexagonal shaped cell would generate less pressure drop. However, there has been indication that the monolith (honeycomb ceramic) would act as a flow resistance zone, creating a high-pressure area in the centre of the catalytic converter which would force flow redistribution to the sides. A simulation of airflow inside the catalytic converter suggests that there is a significant pressure drop inside the catalytic converter, and that backpressure can occur at large pressure drops [58]. The larger the backpressure, the higher the resistance to flow of pollutant gas there is.

It is known that backpressure can be a good indication of a clogged catalytic converter. If there is higher back pressure, there is a larger resistance to gas flow and the mass flow rate, which could indicate that the catalytic converter is clogged. This can result in pressure build-up inside, and the catalytic converter can explode. It is indicated that a back-pressure of 3 psi is the maximum backpressure that could exist inside a catalytic converter.

Another suggestion was to use a metallic honeycomb instead of the usual ceramic monolith honeycomb, where it is manufactured using Fecralloy, a ferritic stainless steel with aluminium, which comes in a broader range of shapes and cpsi than the ceramic, depending on the structure. Using metallic monoliths would provide thinner walls with open frontal areas approaching 90\%, resulting in larger channel diameters [56], therefore resulting in lower pressure drop [31]. However, factors such as cost, weight, and maximum temp. would outweigh the change of material from a ceramic type to a metallic honeycomb [56].

\subsection{Surface Areas}

An experiment by Amirnordin, et al. [55] indicates that at a higher surface area, there would be a significant improvement in chemical properties on the monolith structure (Figure 7). Another reference [30] suggests that a higher surface area and open frontal area are needed, as it would allow more active components (in this case, the catalysts) to be present on the surface of the monolith [59]. 
Table 4. Geometries of single channel for a square and hexagonal shaped cell, and validation of experiments. Adapted from [55].

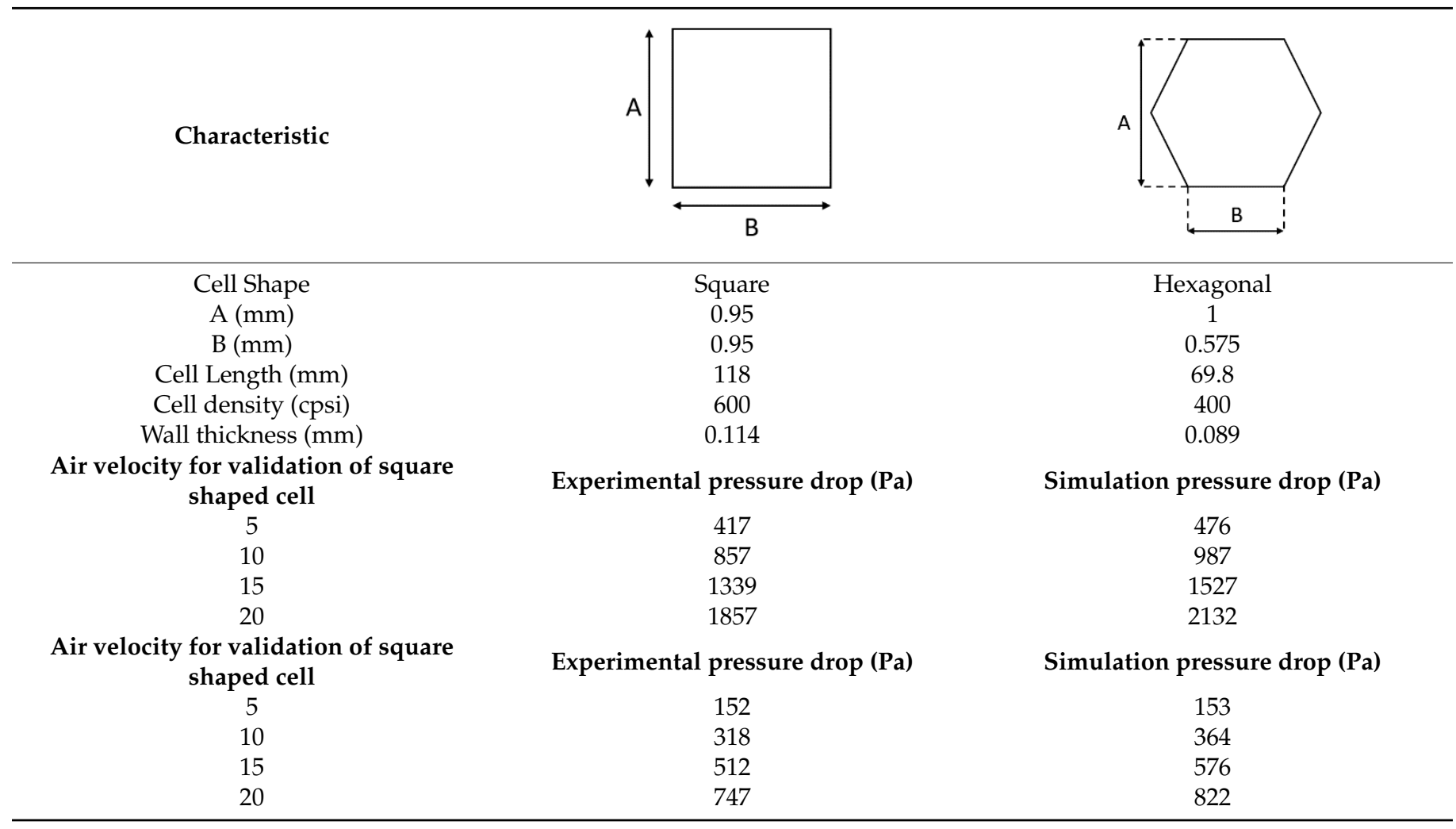

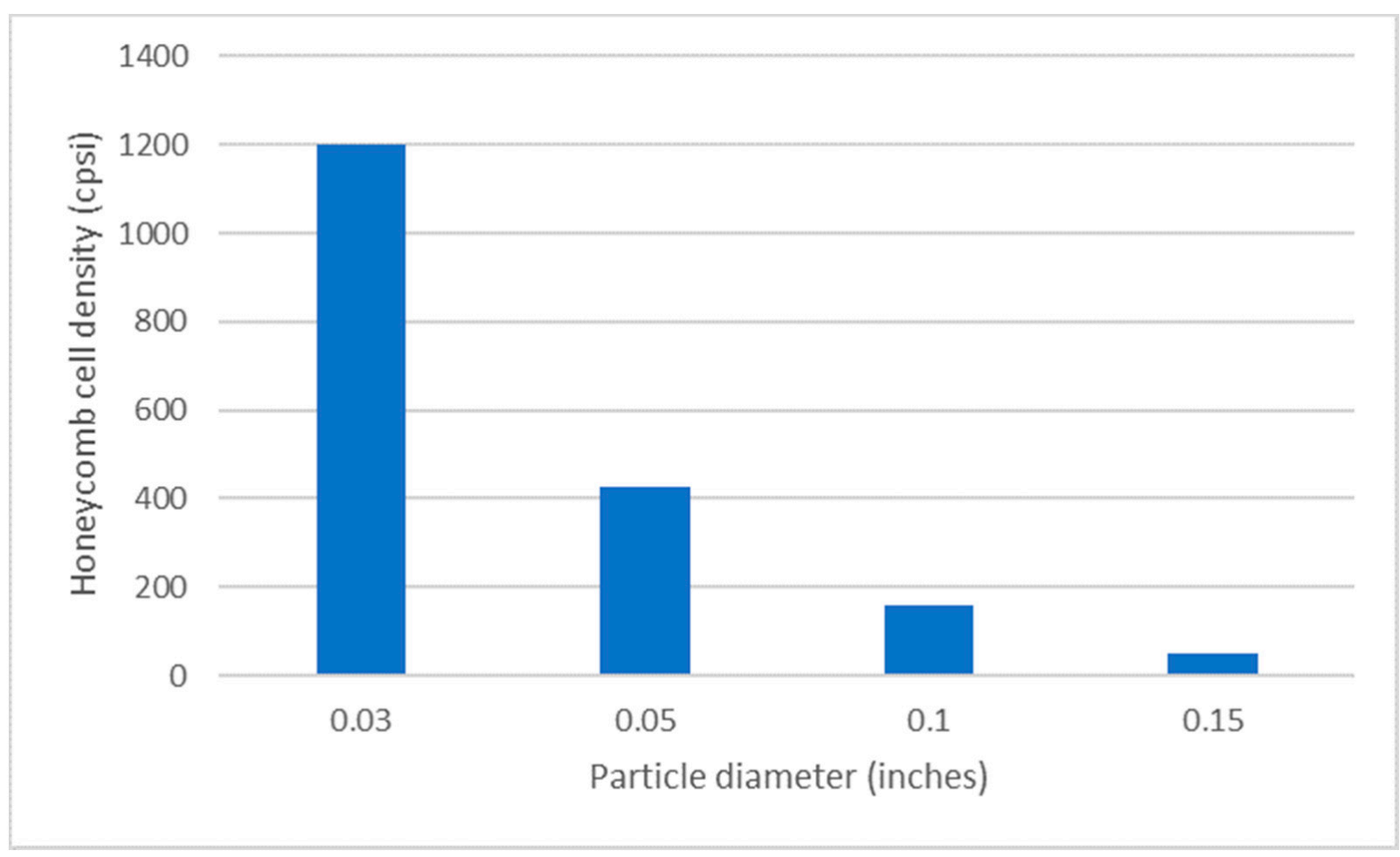

Figure 7. Comparison of a monolith with particulate as a catalyst support at equivalent surface areas. Adapted from [56]. 


\subsection{Air/Fuel Equivalence Ratio}

The air/fuel ratio is also another important condition to consider inside a catalytic converter. It is defined as the ratio between the air mass flow rate and the fuel mass flow rate [59], where the mathematical relationship is shown as Equation (5):

$$
\text { Air - Fuel ratio }\left(\frac{A}{F}\right)=\frac{\dot{m}_{a}}{\dot{m}_{f}}
$$

The reciprocal, the Fuel/Air Ratio, can be defined as shown in Eqn. (6):

$$
\text { Fuel }- \text { Air ratio }\left(\frac{F}{A}\right)=\frac{\dot{m}_{f}}{\dot{m}_{a}}
$$

Typical values of the $\mathrm{A} / \mathrm{F}$ ratio in spark-ignited engines using gasoline fuel is between 12 and 18 (for the F/A ratio, values ranged between 0.056 and 0.083 ).

The stoichiometric air to fuel ratio, also defined as $\lambda=1$, where $\lambda$ is defined as the air/fuel equivalence ratio, is when all three pollutants can be converted [14]. A mathematical relationship can be used to define the air/fuel equivalence ratio [60].

$$
\lambda=\frac{A F R}{A F R_{\text {stoichio }}}
$$

where $A F R$ is the actual air/fuel ratio, and $A F R_{\text {Stoichio }}$ is the stoichiometric air/fuel ratio. Rich air-fuel mixtures have $\lambda<1$, and lean air/fuel mixtures have $\lambda>1$ [60].

For oxidation reactions of $\mathrm{CO}$ and unburned hydrocarbons, they require an environment of excess air i.e., more oxygen is required so they must operate in lean air/fuel mixture settings, where $\lambda>1$ [51]. This is done in a single-bed oxidation catalyst converter, and the $\mathrm{NO}_{x}$ remain practically unaffected.

$\mathrm{NO}_{\mathrm{X}}$ reduction is conducted in a dual-bed catalytic converter, where the exhaust gases flow through a reduction catalyst, where the nitrogen oxides are converted into $\mathrm{N}_{2}, \mathrm{CO}_{2}$ and water vapour, then the unburned hydrocarbons and carbon monoxide are converted in a second bed [51]. Its schematic diagram is shown on Figure 8. Air is provided between the two beds [51]. A rich air-fuel mixture is required for the reduction of $\mathrm{NO}_{\mathrm{x}}$, where $\lambda<1$. However, as the mixture enriches further, small reduction in conversion efficiency occurs, but for leaner mixtures the conversion efficiency is large. For a mixture that is 1.5 percent lean from the stoichiometric, the conversion efficiency goes down by 20 percent. Therefore, the use of catalytic converters for $\mathrm{NO}_{x}$ reduction require tight control of any lean-burn combustion [14].

For a three-way catalytic converter, it allows for the air-fuel ratio to operate close to stoichiometric. When combined with a lambda closed-loop control, it provides the most effective pollutant reduction possible [51]. Figure 9 shows the optimum conversion efficiency of all three exhaust gases at different air-fuel ratio equivalents.

Furthermore, the fuel/air equivalence ratio, $\phi$, can also be defined as the inverse of the actual fuel/air ratio and the stoichiometric fuel/air ratio in Equation (8):

$$
\phi=\frac{\left(\frac{F}{A}\right)_{\text {actual }}}{\left(\frac{F}{A}\right)_{\text {stoichio }}}
$$

Therefore, a graph showing the relationship between the catalyst conversion efficiency and the fuel/air equivalence ratio can be shown in Figure 9 for all three types of exhaust gases. It shows that at the fuel/air equivalence ratios of 0.995 and 1.008, where it is 0.5 percent lean and 0.8 percent rich, respectively, the conversion efficiencies of all three gases are much greater than 80 percent [14]. Hence, the main criterion for the use of the 
three-way catalytic converter, shown in Figure 9 must have tight air-fuel ratio control throughout this operating range [14].
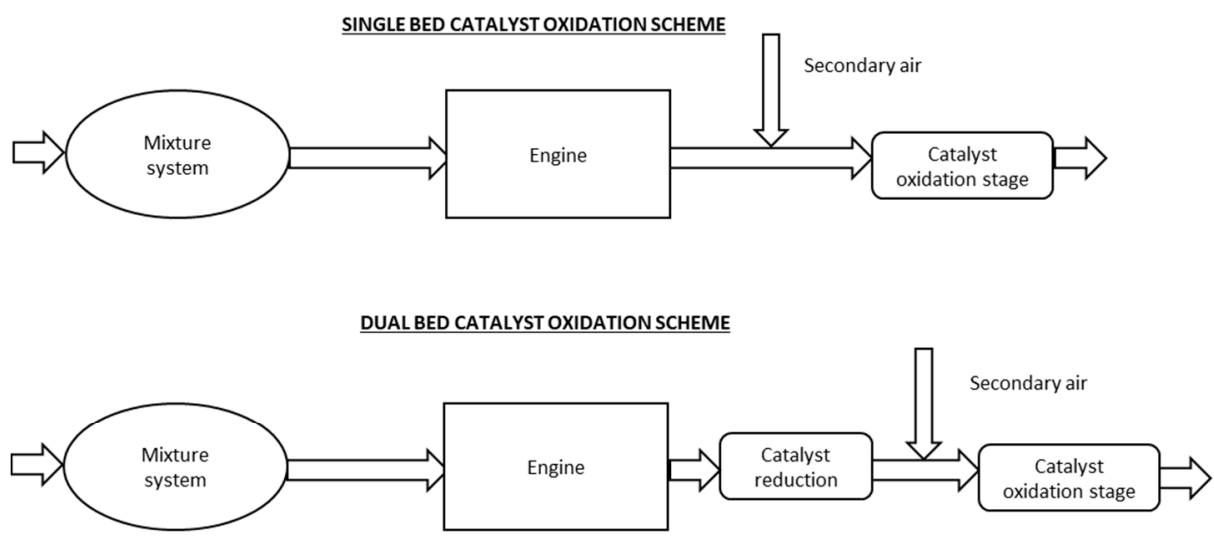

THREE-WAY CATALYTIC SCHEME

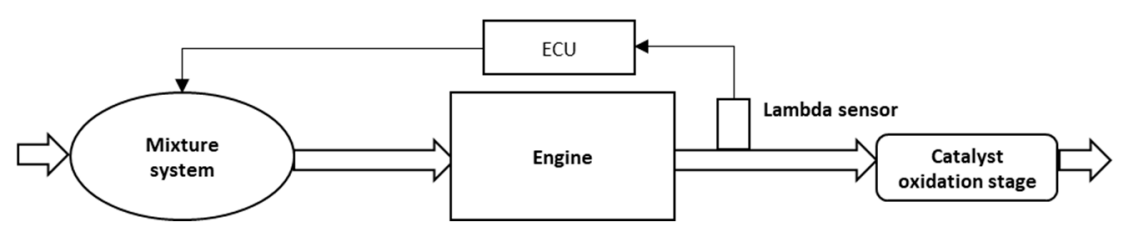

Figure 8. Installation of different types of catalytic converter systems. Adapted from [51].

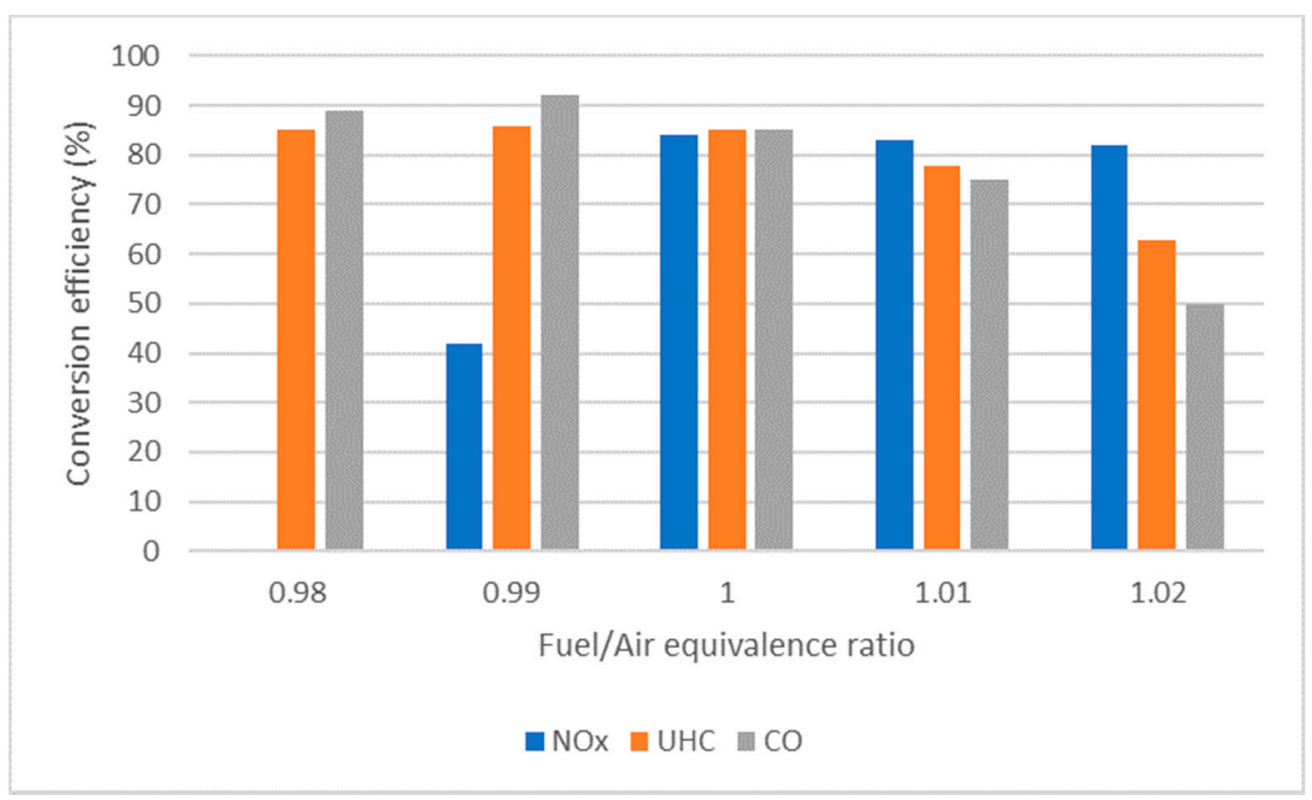

Figure 9. Window for operation of the three-way catalytic converter. Adapted from [14].

\section{Rate of Reaction}

The rate of reaction is defined as the change in the concentration of reactants and products in a certain amount of time, or in simpler terms, the speed of a chemical reaction [12]. The reactants, which in the case of a catalytic converter, would be the exhaust gas that is directly emitted from the combustion engine are conducted inside the catalytic converter, where these reactions produce the products, which produces the non-toxic gases.

To determine how each reaction happens and the conditions that are required to optimize the reaction, the factors that affect the rate of reaction need to be known. The 
key factors that would affect the rate of reaction would be the temperature of the reaction, pressure, the concentration of reactants, surface area, and catalysts [12].

If the temperature of the reaction is increased, the kinetic energy of the molecules (moving energy) would increase. An increase in kinetic energy means that the molecules would gain more energy to move around, as kinetic energy is the energy of an object has because of its motion. This would allow for molecules to move around more frequently and collide with each other at faster speeds, so the reaction rate would increase. So, a high temperature is more favorable for a chemical reaction if the reaction needs to be sped up.

When the exhaust gas temperature is between $450 \mathrm{~K}$ and $500 \mathrm{~K}$, NO conversion efficiency of less than $10 \%$ and concentration of $\mathrm{N}_{2} \mathrm{O}$ generated is less than $0.01 \%$ [61]. It is because as there is a lower temperature in under these temperature conditions, the activity of the catalyst inside the porous medium is too low, so the reaction progresses slowly, making the reaction progress slowly. However, at a temperature at $600 \mathrm{~K}$, the NOx conversion efficiency reaches $68 \%$-highlighting the fact that as the temperature increases, the activity of the catalyst i.e., the kinetic energy of the catalyst increases. A high temperature is favourable.

For a general gaseous reaction, if the pressure increases, this would force the gas particles closer together and so there are more gas molecules in a given volume; allowing for more frequent collisions to occur. Since the rate of reaction is dependent on the number of collisions, the rate of reaction would increase. Therefore, the products of a reaction are produced in a much shorter amount of time. The chances of collision occurring are greater. The effect of pressure on the catalytic activity is investigated by changing the pressure and observing the methane and $\mathrm{CO}_{2}$ conversion. Rising the pressure from 1 to 2 to $4 \mathrm{Bar}$ leads to an increase in methane, $\mathrm{CO}$ and $\mathrm{HCHO}$ conversions, and there is higher residence time. This makes sense as the residence time is the time required to process one (reactor) volume of feed under specific feed conditions. Therefore, if the pressure increases, the gas concentration in a given volume increases, giving a higher residence time [62].

Table 5. Key pollutant gas components, their properties and effect on human health. Adapted from [63].

\begin{tabular}{|c|c|c|}
\hline Pollutant Name and Symbol & Properties & Effect on Human Health \\
\hline Carbon monoxide, $\mathrm{CO}$ & $\begin{array}{l}\text { Highly poisonous, odourless, colourless } \\
\text { and tasteless gas. Flammable. }\end{array}$ & $\begin{array}{l}\text { Great effect on the oxygen delivery to the } \\
\text { body's organs and tissues, which may cause } \\
\text { death. CO poisoning can occur. }\end{array}$ \\
\hline Nitrogen oxides, $\mathrm{NO}_{X}$ & $\begin{array}{c}\text { Mixture of gases composed of Nitrogen } \\
\text { and Oxygen. Nitrogen Oxide, } \mathrm{NO} \text { is } \\
\text { carcinogenic and toxic than Nitrogen } \\
\text { Dioxide, } \mathrm{NO}_{2} .\end{array}$ & $\begin{array}{l}\text { Linked to a wide range of respiratory problems } \\
\text { e.g., cough and sore throat. }\end{array}$ \\
\hline Unburned hydrocarbons, HC & $\begin{array}{l}\text { Produced from incomplete combustion of } \\
\text { organic fuels. These compounds contain } \\
\text { Carbon and Hydrogen bonds only. }\end{array}$ & $\begin{array}{l}\mathrm{HC}, \mathrm{NO} \times \text { and Sunlight can generate the } \\
\text { photochemical smog. Some hydrocarbon } \\
\text { compounds caused irritation to the eye and } \\
\text { damages lungs e.g., Benzene, } 66 \mathrm{H} 6 \text {. At high } \\
\text { concentrations, it can cause asthma and death. }\end{array}$ \\
\hline
\end{tabular}

Table 6. The emissions $(\mathrm{mg} / \mathrm{km})$ of $\mathrm{CO}, \mathrm{NOX}$ and $\mathrm{HC}$ in a gasoline exhaust from vehicles without catalysts and a TWC. Adapted from [63].

\begin{tabular}{ccc}
\hline Gasoline Exhaust & No Catalyst & Three-Way Catalytic Converter \\
\hline CO & 1800 & 300 \\
$\mathrm{NO} \times$ & 3.46 & 0.82 \\
$\mathrm{HC}$ & 1560 & 220 \\
\hline
\end{tabular}

Concerning the surface area, as it increases, 'more molecules are exposed' to the surroundings, so collisions between molecules inside the catalytic converter would occur more frequently, so more products are produced at a higher rate, meaning that the rate of reaction would increase [62]. 


\section{Pollutant Gases Reduction and Environmental Issues}

The effects of vehicle exhaust from burning gasoline and diesel fuels would release toxic exhaust components, where some of the main components are $\mathrm{CO}, \mathrm{NO}_{\mathrm{X}}$ and unburned HC. These pollutants have serious and irreversible impacts on both the human health and environment. The implications that the pollutants have on the human health is highlighted in Table 5 [63].

All of these gases can be minimized by the use of catalytic converters. Using gasoline fuel as an example, the emissions of $\mathrm{CO}, \mathrm{NO}_{\mathrm{X}}$ and $\mathrm{HC}$ is minimized when there is the use of a catalytic converter, as shown in Table 6. Compared to non-catalyst converter gasoline vehicles, the Table shown below shows that the use of a TWC converter can reduce CO, $\mathrm{NO}_{\mathrm{x}}$ and $\mathrm{HC}$ by a factor of six, four and five times respectively. A catalytic converter is just one of the more effective exhaust after treatment devices which might be able to suppler a better efficiency of fuel burning and less GHG emissions [63].

\section{Conclusions and Outlook}

Herein an overview of TWC converters from an educational perspective has been presented. The function of TWC converters is essential as they reduce harmful emissions otherwise emitted to the atmosphere. TWC converters are preferred over two-ways as they are able to remove a wider variety of pollutants. The main parts of a TWC are: (1) the honeycomb, for which cordierite is the most used compound; (2) the washcoat, typically formed by $\mathrm{Al}_{2} \mathrm{O}_{3}$ or metal oxides; (3) and the catalyst support, where PMG solutions are common. The working temperature on TWC covers a wide range, although typical operating temperatures are between $450-500{ }^{\circ} \mathrm{C}$. At these temperatures, $\mathrm{CO}$ and HC conversions range between $90-99.9 \%$. For TWC, the air-fuel ratio can be close to stoichiometric values which is an advantage from an operational point of view. The future challenges of TWC will be closely related to emission control policies. Even though during the past decades significant progress have been carried out for emission control, further restrictions are envisaged for the coming decades to improve the overall quality of our atmosphere. Thus, in this sense TWC will play a key role. These challenges will lead to new developments of TWC and extensive research (i.e., catalyst with better behavior at cold start emissions). All in all, this work is a useful guide to gather a better understanding of TWC converters, essential devices for environmental control.

Author Contributions: Conceptualization, E.K. and T.R.R.; methodology, E.K. and F.M.B.-M.; validation, F.M.B.-M. and T.R.R.; formal analysis, E.K., F.M.B.-M. and T.R.R.; investigation, E.K., F.M.B.-M. and T.R.R.; resources, T.R.R.; data curation, E.K.; writing-original draft preparation, E.K. and F.M.B.M.; writing—review and editing, E.K., F.M.B.-M. and T.R.R.; visualization, T.R.R.; supervision, T.R.R.; project administration, T.R.R.; funding acquisition, T.R.R. All authors have read and agreed to the published version of the manuscript.

Funding: Financial support was provided by the Department of Chemical and Process Engineering at the University of Surrey.

Institutional Review Board Statement: Not applicable.

Informed Consent Statement: Not applicable.

Conflicts of Interest: The authors declare no conflict of interest.

\section{References}

1. EPA. Carbon Pollution from Transportation 2020. Available online: https:/ /www.epa.gov/transportation-air-pollution-andclimate-change/carbon-pollution-transportation (accessed on 16 May 2021).

2. Hannappel, R. The impact of global warming on the automotive industry. AIP Conf. Proc. 2017, 1, 060001. [CrossRef]

3. Kroeze, C. Nitrous oxide and global warming. Sci. Total Environ. 1994, 143, 193-209. [CrossRef]

4. European Environment Agency. Greenhouse Gas Emissions from Transport in Europe. European Environment Agency 2019. Available online: https:/ / www.eea.europa.eu/data-and-maps/indicators/transport-emissions-of-greenhouse-gases/transportemissions-of-greenhouse-gases-12 (accessed on 16 May 2021).

5. Baruch, J.J. Combating global warming while enhancing the future. Technol. Soc. 2008, 30, 111-121. [CrossRef] 
6. Hydrogen Council. Hydrogen Scaling Up: A Sustainable Pathway for The Global Energy Transition. Available online: www. hydrogencouncil.com (accessed on 16 May 2021).

7. Desantes, J.; Molina, S.; Novella, R.; Lopez-Juarez, M. Comparative global warming impact and NOX emissions of conventional and hydrogen automotive propulsion systems. Energy Convers. Manag. 2020, 221, 113137. [CrossRef]

8. Datye, A.K.; Votsmeier, M. Opportunities and challenges in the development of advanced materials for emission control catalysts. Nat. Mater. 2020, 1-11. [CrossRef]

9. Lazkar, A.; Mao-Chang, L. Probing the Operational Temperatures of Vehicular Catalytic Converters Using Clumped Isotopes in Exhaust CO2. In Proceedings of the EGU General Assembly Conference Abstracts, Vienna, Austria, 4-13 April 2018.

10. Zeng, F.; Finke, J.; Olsen, D.; White, A.; Hohn, K.L. Modeling of three-way catalytic converter performance with exhaust mixtures from dithering natural gas-fueled engines. Chem. Eng. J. 2018, 352, 389-404. [CrossRef]

11. Avneet Kahlon, T.T. Catalytic Converters. In Chemistry LibreTexts. Available online: https://chem.libretexts.org/Bookshelves/ Physical_and_Theoretical_Chemistry_Textbook_Maps/Supplemental_Modules_(Physical_and_Theoretical_Chemistry) /Kinetics/07\%3A_Case_Studies-_Kinetics/7.01\%3A_Catalytic_Converters (accessed on 16 May 2021).

12. Brown, T.E.; LeMay, H.E.; Bursten, B.E.; Murphy, C.; Woodward, P.; Stoltzfus, M.E. Catalytic Converters. In Chemistry: The Central Science; Pearson: London, UK, 2018.

13. Clark, J. The Collision Theory of Reaction Rates 2003. Available online: https://www.chemguide.co.uk/physical/basicrates/ introduction.html (accessed on 16 May 2021).

14. Milton, B.E. Handbook of Air Pollution from Internal Combustion Engines. In Control Technologies in Spark-Ignition Engines; Elsevier: Amsterdam, The Netherlands, 1998. [CrossRef]

15. Kummer, J. Catalysts for automobile emission control. Prog. Energy Combust. Sci. 1980, 6, 177-199. [CrossRef]

16. Shelef, M.; McCabe, R. Twenty-five years after introduction of automotive catalysts: What next? Catal. Today 2000, 62, 35-50. [CrossRef]

17. Belton, D.N.; Taylor, K.C. Automobile exhaust emission control by catalysts. Curr. Opin. Solid State Mater. Sci. 1999, 4, 97-102. [CrossRef]

18. Burch, R. Knowledge and Know-How in Emission Control for Mobile Applications. Catal. Rev. Sci. Eng. 2004, 46, 271-334. [CrossRef]

19. Farrauto, R.J.; Deeba, M.; Alerasool, S. Gasoline automobile catalysis and its historical journey to cleaner air. Nat. Catal. 2019, 2, 603-613. [CrossRef]

20. Deutschmann, O.; Grunwaldt, J.-D. Abgasnachbehandlung in mobilen Systemen: Stand der Technik, Herausforderungen und Perspektiven. Chem. Ing. Tech. 2013, 85, 595-617. [CrossRef]

21. Venkateswarlu, K.; Kumar, R.A.; Krishna, R.; Sreenivasan, M. Modeling and fabrication of catalytic converter for emission reduction. Mater. Today: Proc. 2019, 33, 1093-1099. [CrossRef]

22. Braun, J.; Hauber, T.; Többen, H.; Zacke, P.; Chatterjee, D.; Deutschmann, O.; Warnatz, J. Influence Of Physical And Chemical Parameters On The Conversion Rate Of A Catalytic Converter: A Numerical Simulation Study. In Proceedings of the SAE 2000 World Congress, Cobo Center, Detroit, MI, USA, 6-9 March 2000. [CrossRef]

23. Haldar, S.K. Exploration Guide. In Platinum-Nickel-Chromium Deposits; Elsevier: Amsterdam, The Netherlands, 2017. [CrossRef]

24. Vanderveer, R.T.; Chandler, J.M. The Development of a Catalytic Converter for the Oxidation of Exhaust Hydrocarbons. SAE Tech. Pap. Ser. 1959. [CrossRef]

25. Kalam, M.A.; Masjuki, H.H.; Redzuan, M.; Mahlia, T.M.I.; Fuad, M.A.; Mohibah, M.; Halim, K.H.; Ishak, A.; Khair, M.; Shahrir, A.; et al. Development and test of a new catalytic converter for natural gas fuelled engine. Sadhana Acad. Proc. Eng. Sci. 2009, 34, 467-481. [CrossRef]

26. Majewski, W.A. DieselNet Technology Guide 2000. In Emission Control Catalysts; 2002; Available online: https:/ / dieselnet.com/ tech/catalysts.php (accessed on 16 May 2021).

27. Samuels, G.; Rose, A.; David, G.; Hooker, J.N. Energy Conservation in Transportation. Adv. Energy Syst. Technol. 1982, 187-297. [CrossRef]

28. Golunski, S.E. Final Analysis. Platin. Met. Rev. 2007, 51, 162. [CrossRef]

29. USA News Group. Use of Palladium in Catalytic Converters Driving Demand for the Precious Metal 2019. Available online: https:/ / www.prnewswire.com/news-releases/use-of-palladium-in-catalytic-converters-driving-demand-for-the-preciousmetal-300937620.html (accessed on 16 May 2021).

30. Thakur, P. Advanced Mine Ventilation. Diesel Exhaust Control 2019, 157-187. [CrossRef]

31. Durilla, M.; Hizny, W.J.; Mack, S. Carbon monoxide oxidizers. In Heat Recover Steam Generator Technology; Elsevier: Amsterdam, The Netherlands, 2017. [CrossRef]

32. Green Chemistry: An Inclusive Approach. Focus Catal. 2018, 2018, 7. [CrossRef]

33. Dell, R.M.; Moseley, P.T.; Rand, D.A. Development of Road Vehicles with Internal-Combustion Engines. In Towards Sustainable Road Transport; Elsevier: Amsterdam, The Netherlands, 2014. [CrossRef]

34. Govender, S.; Friedrich, H.B. Monoliths: A Review of the Basics, Preparation Methods and Their Relevance to Oxidation. Catal 2017, 7, 62. [CrossRef]

35. Mahyon, N.I.; Li, T.; Martinez-Botas, R.; Wu, Z.; Li, K. A new hollow fibre catalytic converter design for sustainable automotive emissions control. Catal. Commun. 2019, 120, 86-90. [CrossRef] 
36. Siemund, S.; Leclerc, J.; Schweich, D.; Prigent, M.; Castagna, F. Three-way monolithic converter: Simulations versus experiments. Chem. Eng. Sci. 1996, 51, 3709-3720. [CrossRef]

37. Kašpar, J.; Fornasiero, P.; Graziani, M. Use of CeO2-based oxides in the three-way catalysis. Catal. Today 1999, 50, 285-298. [CrossRef]

38. Leman, A.; Afiqah, J.; Rahman, F.; Feriyanto, D.; Zakaria, S.; Rahmad, R. Catalytic Converter Developed by Washcoat of $\gamma$-Alumina on Nickel Oxide (Nio) Catalyst in FeCrAl Substrate for Exhaust Emission Control: A Review. In Proceedings of the MATEC Web Conference 2016; (online). Available online: https://www.matec-conferences.org/articles/matecconf/abs/2016/2 3/contents/ contents.html (accessed on 16 May 2021). [CrossRef]

39. Converters, C. Catalytic Converters 2020. Available online: https:/ /www.catalyticconverters.com/construction/ (accessed on 16 May 2021).

40. Fornalczyk, A.; Saternus, M. Removal of platinum group metals from the used auto catalytic converter. Metalurgija 2009, 48, 133-136.

41. Hoffman, J.E. Britannica Encyclopedia: Platinum Group 2018. Available online: https://www.britannica.com/science/platinumgroup (accessed on 16 May 2021).

42. Johnson, M. Properties of Platinum Group Metals 2020. Available online: http://www.platinum.matthey.com/about-pgm/ applications / properties-of-pgm (accessed on 16 May 2021).

43. Martinez, N.; Amado, M.; Guerrero, M.P. Modeling the vibrations in a catalytic converter for diesel engines. In Proceedings of the SIMULIA Cust Conference, Providence, RI, USA, 19 May 2011.

44. Chen, Y.; Bowman, J.; Harris, J. Catalyst Converter Canning Simulation Studies. SAE Tech. Pap. Ser. 2003. [CrossRef]

45. Fernandes, S.; Martins, S.C.; Olson, J.; Peters, B. The Role of New Catalytic Converter Mounting Materials in Providing Durability and Efficiency. SAE Tech. Pap. Ser. 2002. [CrossRef]

46. Spreen, K.B.; Heimrich, M.J.; Hornback, L.R.; Montalbano, A.J. Container Deformation Procedure for Ceramic Monolith Catalytic Converters. SAE Tech. Pap. Ser. 2000. [CrossRef]

47. Taylor, W. CFD Prediction and Experimental Validation of High-Temperature Thermal Behavior in Catalytic Converters. $S A E$ Tech. Pap. Ser. 1999. [CrossRef]

48. Gao, J.; Tian, G.; Sorniotti, A.; Karci, A.E.; Di Palo, R. Review of thermal management of catalytic converters to decrease engine emissions during cold start and warm up. Appl. Therm. Eng. 2019, 147, 177-1879. [CrossRef]

49. Lee, S.; Bae, C.; Lee, Y.; Han, T. Effects of Engine Operating Conditions on Catalytic Converter Temperature in an SI Engine. SAE Tech. Pap. Ser. 2002. [CrossRef]

50. Choice Reviews Online. In Internal Combustion Engine Fundamentals; McGraw-Hill Education: New York, NY, USA, 1988; Volume 26, pp. 26-943. [CrossRef]

51. Handbook of Air Pollution from Internal Combustion Engines; Elsevier: Amsterdam, The Netherlands, 1998. [CrossRef]

52. Whelan, I.; Timoney, D.; Smith, W.; Samuel, S. The Effect of a Three-Way Catalytic Converter on Particulate Matter from a Gasoline Direct-Injection Engine During Cold-Start. SAE Int. J. Engines 2013, 6, 1035-1045. [CrossRef]

53. CITA. CITA Study No 4-Influence of Catalyst Temperature on Effectiveness of In-Service Testing; AEA Technology: Harwell, UK, 1994.

54. Korin, E.; Reshef, R.; Tshernichovesky, D.; Sher, E. Improving Cold-Start Functioning of Catalytic Converters by Using PhaseChange Materials. SAE Tech. Pap. Ser. 1998. [CrossRef]

55. Amirnordin, S.H.; Seri, S.M.; Salim, W.S.-I.W.; Rahman, H.A.; Hasnan, K. Pressure Drop Analysis of Square and Hexagonal Cellsand its Effects on the Performance of Catalytic Converters. Int. J. Environ. Sci. Dev. 2011, 239-247. [CrossRef]

56. Heck, R.M.; Gulati, S.; Farrauto, R.J. The application of monoliths for gas phase catalytic reactions. Chem. Eng. J. 2001, 82, 149-156. [CrossRef]

57. Cornejo, I.; Nikrityuk, P.; Hayes, R.E. Effect of substrate geometry and flow condition on the turbulence generation after a monolith. Can. J. Chem. Eng. 2020, 98, 947-956. [CrossRef]

58. Ibrahim, H.A.; Abdou, S.; Ahmed, W.H. Understanding Flow through Catalytic Converters. In Proceedings of the 5th International Conference of Fluid Flow, Heat and Mass Transfer (FFHMT'18), Orléans, ON, Canada, 7-9 June 2017. [CrossRef]

59. Heywood, J.B. Pollutant formation and control in spark ignition engines. Symp. (Int.) Combust. 1975, 15, 1191-1211. [CrossRef]

60. Al-Arkawazi, S.A.F. Analyzing and predicting the relation between air-fuel ratio (AFR), lambda ( $\lambda$ ) and the exhaust emissions percentages and values of gasoline-fueled vehicles using versatile and portable emissions measurement system tool. SN Appl. Sci. 2019, 1, 1370. [CrossRef]

61. Zuo, Q.; Xie, Y.; Jiaqiang, E.; Zhu, X.; Zhang, B.; Tang, Y.; Zhu, G.; Wang, Z.; Zhang, J. Effect of different exhaust parameters on NO conversion efficiency enhancement of a dual-carrier catalytic converter in the gasoline engine. Energy 2020, 191, 116521. [CrossRef]

62. Levenspiel, O. Chemical Reaction Engineering. Ind. Eng. Chem. Res. 1999, 38, 4140-4143. [CrossRef]

63. Jie, L. Environmental Effects of Vehicle Exhausts, Global and Local Effects-A Comparison between Gasoline and Diesel. Digit. Vetensk. Ark. 2011, 27. Available online: https://www.diva-portal.org/smash/get/diva2:427347/FULLTEXT01.pdf (accessed on 16 May 2021). 